\title{
A többszintü kormányzás kifejlődése a regionális politikában - tanulságok az Észak-alföldi régióból
}

A tanulmány a magyar regionális politika terén kialakult partnerséget és kapcsolati hálót elemzi az Északalföldi régió példáján. Megvizsgálja, hogy a kapcsolatok alakulását mennyire kényszeritette ki az európai uniós rendszerekhez való alkalmazkodás nyomása. A hálózatépités a legtöbb szervezetben bevált alkalmazkodási stratégia. Az esettanulmányként választott régióban a szervezetek kapcsolathálója nem egyenletes: egyes szereplök centrális helyzete mellett másoknak csak kevéssé sikerült beágyazódni a kapcsolatok hálózatába. A regionális politika köz-, magán- és civil szereplói kapcsolathálójának vizsgálata során a kutatás feltárta ezek párhuzamosan folyó együttmüködési és versengési formáit. A szerzö legföbb következtetése, hogy az EU-integráció által kiváltott alkalmazkodási folyamatok regionális szint alatt intézményi konfliktusokat szülnek, mig országos szinten segitették a kapcsolatok fejlödését.

\section{Bevezetés, a kutatás előzményei}

Magyarországon már régóta hangoztatott vélemény, hogy a régiós szintü fejlesztések végrehajtásához és ellenőrzéséhez mindenekelőtt a regionális politika szövevényes intézményi hálózatának kiépülése szükséges, és ez a megállapítás fokozottan érvényes azokra a fejlesztésekre, amelyek európai uniós forrásból történnek. A fejlesztési pénzek tényleges hasznosulása ugyanakkor nagyban függ a regionális intézmények hatékony mủködésétől és azok egymással való kapcsolatától is. Amennyiben tehát a tervezett fejlesztések megvalósulását befolyásoló tényezőket, illetve magukat a fejlesztéseket akarjuk értékelni, akkor mindenképpen figyelmet kell fordítanunk a regionális politikában érintett intézmények és szervezetek vizsgálatára.

Hazánkban nincsenek hagyományai a regionális együttmüködéseknek - a jelenlegi NUTS II. régiókat is az EU elvárásai miatt hozták létre a meglévő megyék összevonásával. A szocialista rendszernek a decentralizációt lehetetlenné tevő irányítási rendszere eleve alapjaiban korlátozott mindenféle térségi együttmüködést (Pálné 2005). Éppen ezért tartottuk szülkségesnek a regionális intézményrendszer és a kapcsolati hálózatok

Trón Zsuzsanna egyetemi tanársegéd a Debreceni Egyetem Közgazdaságtudományi Karán. E-mail: zsuzsanna. tron@econ.unideb.hu. A kutatás lefolytatásában nyújtott segitségért a szerzó köszönetet mond Szabó llonának és Kovács Péternek. A tanulmányhoz füzött hasznos megjegyzésekért köszönet illeti Pálné Kovács llonát, Dombi Pétert, Balcsók Istvánt, Sebestyén Etelkát, Ricz Juditot, és végül, de nem utolsó sorban a DE KTK Világgazdaság és Nemzetközj Kapcsolatok Tanszék vezetöjét, Dr. Láng Esztert. A fennmaradó hibák a szerzöt terhelik. 
formálódásának nyomon követését. A jelen tanulmányban bemutatott kutatásban ezért azt vizsgáltuk, hogy a partnerség hogyan fejlödik, illetve fejlödött ki egy régióban (a mi esetünkben az Észak-alföldi régióban), és mennyire játszik szerepet a regionális fejlesztési stratégiák kialakításában.

Munkánk közvetlen elözményének egy az ADAPT 5. keretprogramon belïl a „Kormányzás, polgárság, bővítés" (Governance, citizenship and enlargement) tematikus részkutatás keretében végrehajtott európai uniós projekt tekinthető (ADAPT 2003), amelyet 2002-ben az EU több országában is lefolytattak (Getimis 2003). Az ADAPT program keretében elvégzett kutatás azt vizsgálta, hogy az újonnan csatlakozó országok közül Magyarország és Lengyelország hogyan alkalmazkodott a regionális politika területén érvényesülö többszintủ kormányzási rendszerhez ${ }^{1} \mathrm{Az}$ adaptációs folyamat fogalmi tanuláson, intézményi és politikai alkalmazkodáson keresztül zajlott le, felhasználva a korábban csatlakozott (főként a kohéziós) országok tapasztalatait is. A projektnek kettős célja volt: egyfelöl értékelni kívánták a közpolitika európaizálódásának ${ }^{2}$ kihatását az EU három hagyományosan unitárius kohéziós államának kormányzati struktúrájára, másfelöl meg kívánták vizsgálni a kihívásra adott válaszaikat, felkészültségüket és alkalmazkodásukat az európai környezethez. További célkitüzés volt, hogy a csatlakozó országok hasznositsák a meglévő tapasztalatokat, felismerjék a megfelelő reformok lehetőségét, amelyekkel megkönnyíthetik a közpolitika-struktúrájuk alkalmazkodását az új európai feltételekhez a regionális politika területén.

A jelen tanulmányt megalapozó vizsgálatban (továbbiakban ADAPT) résztvevő magyar kutatók $k^{3}$ a regionális politikában megjelenő többszintủ kormányzás kifejlődésének vizsgálatához és bemutatásához a Dél-dunántúli régiót választották ki tanulmányozásra (Futó et al 2002). Kutatásunkban $\mathrm{mi}$ is a Dél-dunántúli régióban alkalmazott módszereket, feltárt és bemutatott sajátosságok elemzési rendszerét alkalmaztuk, elsősorban a későbbi összehasonlíthatóság érdekében, de azért is, mert a már kész kutatási terv és kérdöív nagyban megkönnyítette és meggyorsította az Észak-alföldi régióban megjelenő többszintů kormányzási rend feltérképezésére irányuló munkát.

\section{A többszintủ kormányzás jelentése}

A többszintűkormányzás (multi-level governance) gyökerei egészena neofunkcionalizmus kialakulásáig nyúlnak vissza (Marks - Hooghe 2004). Eszerint az Európai Unióban egy új politikaalkotási folyamat alakult ki, amelyben a központi kormányzatok - bár létfontosságú szerepük megmarad - nem rendelkeznek többé a döntéshozás monopóliumával. A döntéshozás felelősségében a kormányzatok a Bizottsággal és a regionális, illetve helyi szereplőkkel osztoznak. Az európai intézmények ebben a megközelítésben befolyásos és független szereplöi az uniós politika kialakításának, a regionális és helyi szereplők pedig mobilizálhatók és mobilizálódni is fognak e folyamat során. A többszintü kormányzás modellje alapján a szubnacionális aktorok gyakran legalább olyan fontos-

\footnotetext{
' A kutatás a regionális politikán kívül a környezetvédelem területén megjelenö többszintü kormányzás folyamatait is vizsgálta (Futó et al, 2002).

2 Az európaizáció folyamata azt jelenti, hogy az integráció elörehaladtával a szupranacionális intézmények és egyezmények szerepe egyre növekszik (Börzel 2001:137).

${ }^{3}$ A világgazdasági kutató intézettöl Fleisher Tamás, Vida Krisztina, Szaitz Marianna és Futó Péter, valamint a Regionális Kutatások Központjától Pálné Kovács llona és Horváth Gyula.
} 
sá válnak ebben a folyamatban, mint a központi kormányok és az EU intézményei. Ez a tendencia már csak azért is jellemzővé válik, mert a központi kormányzatok nem képesek mindig „ajtónállóként” funkcionálni az uniós testületek és a szubnacionális szereplök közt (Sutcliff 2000).

Mindenképpen ki kell emelni, hogy a többszintü kormányzás megközelítés képviselöi (1) elfogadják és elismerik a központi kormányzatok fontosságát az EU politikaalkotási folyamatában, (2) szerintük is vannak erősebb és kevésbé erős szubnacionális szereplök (lásd például a német tartományokat), és (3) a különböző politikai szektoroknak eltérő fontosságuk van a politikaalakítási folyamat egyes lépcsőfokain.

$\mathrm{Az}$ előzőkkel szembeni kontrasztként említhető a kormányközi modell, amelyet az angol kifejezésből eredően „intergovernmentalizmusként” is emlegetnek. A kormányközi megközelítést alkalmazók szerint ugyanis az Európai Unióban a kormányok maradtak a legfontosabb szereplők, és a döntések a köztük lévő alkuk eredményeként születnek meg ${ }^{4}$. Ebből következően a nemzeti szint alatti szereplök gyakorlatilag csak marginális jelentősséggel bírnak az európai döntéseket illetően. Ha képesek is elérni valamilyen eredményt, vagy hatást tudnak gyakorolni a döntéshozatalra, azt a kormányukra tett befolyásukon keresztül tudják érvényesíteni - de ez természetesen mindig függ az adott államszerkezettől is (Pálné 1999:72-73).

\section{A vizsgálati eljárás jellemzői}

A mintaként szolgált ADAPT projekt módszertana komparatív közpolitika-elemzési módszereken nyugszik, amely annak feltárására koncentrált, hogy az európaizációs folyamatnak milyen hatása van a helyi intézményi struktúrákra, illetve a kormányzati rendszerre. Ez főleg a résztvevő országokban kiválasztott esettanulmányok szocio-ökonómiai adatainak kvantitatív és kvalitatív elemzését, strukturált interjúk készítését, valamint a nemzeti és szubnacionális szintek Társadalmi Kapcsolatháló Elemzését (SNA ${ }^{5}$ ) jelentette. A fenti módszertani megközelítés lehetővé teszi a bonyolult rendszerek közti kapcsolatok összehasonlítását, és egyaránt koncentrál a szereplők közti kapcsolatokra, valamint a strukturális és kulturális jellemzőkre.

A mi kutatásunk során feltett kérdések elsősorban a Strukturális Alapok programjainak megvalósítását vizsgálták.

A felmérés folyamán 39 strukturált interjút készítettünk a regionális politikában érintett különböző köz-, illetve magánszférába tartozó érintett intézmények prominens szakértőivel az Észak-alföldi régióban. Az interjúk készitése közben több ponton is problémásnak találtuk az eredeti SNA módszer alkalmazhatóságát, azonban a kritikai értékeléshez mélyebb elméleti elemzésre lenne szükség, amit a jelen cikk keretei nem tesznek lehetővé. A tanulmányban ebből következően csak a régióra vonatkozó legfontosabb gyakorlati észrevételeket emeljük ki.

\footnotetext{
4 Jól ismertek az Európa Tanács üléseinek csomag-összeállitísos (package-deal) vagy kapocstechnikával (linkagedeal) összeállított tárgyalási folyamatai. Ezekben az eredetileg egymással össze nem függö ügyek összekapcsolásával és a nulla végösszegü játszmákat pozitívösszegü alkukká alakitva érnek el olyan átfogó politikai kompromisszumokat, amelyek minden résztvevö számára elfogadhatóak. Lásd részletesebben: (Kende-Szücs 2003:215).

s SNA = Social Network Analysis, Társadalmi Kapcsolatháló Elemzés egy standard számítógépes algoritmus használatával, az UCINET szoftver segítségével. (Borgatti, S.P., Everett, M.G. and Freeman, L.C. 2002.)
} 
A minta kiválasztása. Az interjúalanyok kiválasztását a következő mintavételi kritériumok határozták meg. A megkérdezett érintettek köre (intézmények, vállalatok, szervezetek) magában foglal minden olyan jelentős, fontos és befolyásos közszférába tartozó állami és önkormányzati tulajdonú, illetve magánszereplőt, akik az Észak-alföldi régióban a regionális fejlesztés terén szerepet játszanak. Itt emeljük ki, hogy jelen írás csak a régión belüli intézmények vizsgálatát mutatja be. Az érintettek kiválasztásában támpontot jelentett még a Dél-dunántúli régióban megkérdezettek köre, a megkérdezettek listáját azonban mindenképpen az Észak-alföldi régió sajátosságaihoz kellett igazítanunk. Az alábbi kiigazitásokat tettük.

Az Észak-alföldi régió nagy területén folyik mezőgazdasági termelés, és az interjúk készítése során egyre inkább nyilvánvalóvá vált, hogy a Dél-dunántúli régióban is megkérdezett kereskedelmi- és iparkamarákon kívül az agrárkamarákat is be kell vonni a vizsgálatba. Az ADAPT vizsgálatban ezt nem tették meg. Az agrárkamarákra vonatkozó kérdéseink azonban csak a felmérés megkezdése után kerültek be a kérdöívbe, így, bár a véleményük szerepel a jelen munkában, a kapcsolati hálózatba való illeszkedésüket nem tudtuk vizsgálni. Ezt a hiányosságot egy újabb felmérés tudja majd pótolni.

Egy másik fontos különbség, hogy az Észak-alföldi régió mindhárom megyéjében nemcsak a megyei fejlesztési tanácsokat, hanem azok ügynökségeit is fel kellett keresnünk. A Dél-dunántúli régióban (megyei ügynökségek nem lévén) csak a megyei fejlesztési tanácsok kerültek a vizsgálatba. A Területfejlesztési Törvény 1996-ban elöírta, hogy minden megyében létre kell hozni a megyei területfejlesztési tanácsokat, így tehát az Észak-alföldi régió mindhárom megyéjében mủködik területfejlesztési tanács, akárcsak Dél-Dunántúlon. A törvény azt azonban nem szabályozza, hogy müködtessen-e a tanács, és ha igen, milyen formában, operatív szervezetet. A vizsgált régióban kétféle megoldás alakult ki: Jász-Nagykun-Szolnok és Hajdú-Bihar megyében az operatív döntés-előkészitő feladatokat közhasznú társaság formában müködő fejlesztési ügynökségek látják el, míg Szabolcs-Szatmár-Bereg megyében a fejlesztési ügynökség a Területfejlesztési Tanács belső szervezeti egysége (Helyzetfeltárás 2003:185). A kapcsolati hálóban azonban az agrárkamarákhoz hasonlóan ezek az intézmények sem szerepelnek, mivel a válaszadók nem érzékeltek különbséget a tanács és az ügynökség munkája között!

Problémát okozott - és ez szintén eltérés az ADAPT vizsgálathoz képest -, hogy az Észak-alföldi régióban végzett kutatásban a munkaügyi központokra kérdeztünk rá, melyek megyei szinten müködnek, míg a dél-dunántúli vizsgálatban a Pécsi Regionális Munkaerő-fejlesztő és Képző Központot vizsgálták. A válaszadóink azonban a három megyei munkaügyi központra asszociáltak a "munkaügyi központ” név alatt. Ez sajnos befolyásolta a hálózatban betöltött szerepet, ahogy erre majd a későbbiekben a tanulmány is utal.

A mintában résztvevők köre szektorokra bontva a következő':

- A megkérdezett intézmények valamivel több mint egyharmada a központi, regionális, megyei, kistérségi és települési szintü önkormányzati, illetve adminisztratív szervek közé tartozik. Szerepük föként területi államigazgatási és közszolgáltatási feladatokban összegezhető, megalkotják, koordinálják és végrehajtják a kormányzati politikákat.

6 Az eredetileg összeálitott érintettek listájában történt némi változás, de a kérdóívezés ekkor már elkezdödött. Igy pl. Debreceni Regionális és Innovációs ipari Park helyett a debreceni Nyugati Ipari Park adott interjüt. 
- Az interjúalanyok további több mint egyharmada önálló jogi személyként müködő, de önkormányzati tulajdonban lévő költségvetési szerv, köztestület, közintézmény illetve Kht. és Kft.

- Néhány (5) megkérdezett cég tartozott a magánszférába mint pályázatíró és tanácsadó cég, illetve ipari park.

Bevezettünk egy rövidítési rendszert a megkérdezett szereplö $\mathrm{k}^{7}$ azonosítására:

\begin{tabular}{|c|c|c|}
\hline 1 & Országos Fejlesztési Hivatal & MTRFH \\
\hline 2 & Nemzeti Fejlesztési Hivatal & $\mathrm{NFH}$ \\
\hline 3 & Magyar Regionális Fejlesztési és Urbanisztikai Kht. & VÁTI \\
\hline 4 & $\begin{array}{l}\text { Foglalkoztatási és Munkaügyi Minisztérium (HEFOP és EKK IH } \\
\text { föigazgatóság) }\end{array}$ & HEFOP \\
\hline 5 & Gazdasági és Közlekedési Minisztérium (GVOP föo.) & GVOP \\
\hline 6 & Gazdasági és Közlekedési Minisztérium (KIOP föo.) & KIOP \\
\hline 7 & Földműv. és Vidékfejl. Min., Közösségi Kifizetések Szabályozási és Felügyeleti Föo. & AVOP \\
\hline 8 & JNSZ Megyei Közgyűlés & JNSZ-KGY \\
\hline 9 & HB Megyei Közgyülés & HB-KGY \\
\hline 10 & SZSZB Megyei Közgyủlés & SZSZB-KGY \\
\hline 11 & Észak-alföldi Regionális Fejlesztési Tanács & RFT \\
\hline 12 & JNSZ Megyei Területfejlesztési Tanács & JNSZTFT \\
\hline 13 & JNSZ Megyei Területfejlesztési Ügynökség & JNSZ MFÜ \\
\hline 14 & HB Megyei Területfejlesztési Tanács & HBTFT \\
\hline 15 & HB Megyei Területfejlesztési Ügynökség & HB MFU \\
\hline 16 & SZSZB Megyei Területfejlesztési Tanács & SZSZBTFT \\
\hline 17 & SZSZB Megyei Területfejlesztési Ügynökség & SZSZBMFÜ \\
\hline 18 & JNSZ Kereskedelmi és Iparkamara & JNSZK-KIK \\
\hline 19 & HB Kereskedelmi és Iparkamara & $\mathrm{HB} \cdot \mathrm{KIK}$ \\
\hline 20 & SZSZB Kereskedelmi és Iparkamara & SZSZB-KIK \\
\hline 21 & Debreceni Egyetem & UNIV \\
\hline 22 & Észak-Alföldi Regionális Fejlesztési Ugynölsség Kht. & ÜGYN \\
\hline 23 & Magyar Fejlesztési Bank & BANK \\
\hline 24 & Munkaügyi központ & MUNKA \\
\hline 25 & Eurorégió Ház & $\mathrm{EU}-\mathrm{HAZ}$ \\
\hline 26 & Szolnok város önkormányzata & SZOLN \\
\hline 27 & Debrecen város önkormányzata & DEBR \\
\hline 28 & Nyíregyháza város önkormányzata & NYÍRE \\
\hline 29 & JNSZK Megye kistérségi társulásai & JNSZ-KIST \\
\hline 30 & HB Megye kistérségi társulásai & HB-KIST \\
\hline 31 & SZSZB Megye kistérségi társulásai & SZSZB-KIST \\
\hline 32 & Debreceni Regionális Innovációs és Ipari Park & DIPARK \\
\hline 33 & Nyíregyházi Ipari Park & NYIPARK \\
\hline 34 & Regionális Kutatások Központja & RKK \\
\hline 35 & Pályázatíró, tanácsadó cégek (RVI, Megakom, stb.) & PÁLYCÉG \\
\hline
\end{tabular}

7 A 39 interjú a fenti 35 szereplö és a 3 megyei agrárkamara, valamint a két pályázatíró cég külön-külön megkeresésével együtt adódik. 
A SNA kritikájaként az érintettek kiválasztásának önkényessége mellett más kritikát is meg kell említeni. Az interjú készítése egy személlyel történt, akinek a teljes szervezetet kellett képviselnie, és az összes releváns információval rendelkeznie kellett volna. Gyakran a képviseleti jog és a széleskörü informáltság nem ugyanannál a személynél összpontosul a szervezetben, ezért az interjú készítése elött mindenképpen fel kellett térképezni a szervezetet és a hatásköröket.

A kérdőív felépitése. A kérdőív hat nagyobb egységből állt. Az első blokkban a megkérdezett intézménnyel kapcsolatos általános információkra kérdeztünk rá, úgymint fö tevékenység, jogi státusz, kapcsolat az uniós fejlesztésekkel. A második kérdéskör a regionális problémákra kérdezett rá, a harmadik a regionális szintủ kapcsolatokra és öszszefonódásokra, a negyedik a nemzeti szintü, az ötödik pedig az európai szintú együttműködésekre. Az utolsó, hatodik kérdéscsoport a régióban érzékelhető társadalmi tőke jelenlétét vizsgálta.

\section{A régió rövid bemutatása}

Az Észak-alföldi régió a Dél-alföldi után Magyarország második legnagyobb területü $\left(17.729 \mathrm{~km}^{2}\right)$ statisztikai régiója, és az 1.521 .951 fős népességszámát (2004. jan. 1-jei adat) csak a Közép-magyarországi régió múlja felül. Az ország területének egyötödét (19,1\%), népességének $15,2 \%$-át magában foglaló régió fekvését, adottságait és jövőbeni lehetöségeit tekintve fölöttébb ellentmondásos helyzetben van.

A földrajzi elhelyezkedés egyrészről kedvező, mert, miután három országgal is határos (Szlovákiával, Ukrajnával és Romániával), az európai uniós csatlakozás után hídszerepet tölt be a kelet-nyugati kapcsolatokban, és Ukrajna (rajta keresztül a FÁK-országok) felé az Unió keleti kapujává vált. A „kapuszerep” ebben az irányban minden bizonnyal hosszabb távon fennmarad, míg keleti szomszédunk 2007-re tervezett csatlakozását követően a román határszakasz (a régiót nyúlfarknyi hosszúságban érintő szlovákhoz hasonlóan) belső határrá válik. $\mathrm{Az} \mathrm{EU}$ támogatási politikájában a határ menti területek fejlesztése, a határon átnyúló kapcsolatok erösítése az INTERREG programon keresztül kiemelt prioritást élvez, vagyis megfelelő pályázati aktivitás esetén a térség jelentős külső forrásokhoz juthat hozzá.

A régió ugyanakkor leginkább éppen a fekvése miatt vált egyértelmüen a rendszerváltás vesztesévé, mivel a hagyományosan elmaradott térség kimaradt a Nyugatról érkező müködőtőke célterületei közül, és így vajmi kevés esélye maradt a lemaradás csökkentésére. Az országon belïli kedvezőtlen helyzetet érzékelteti az a tény is, hogy a bruttó hazai termék alig 10,2\% -át állítják elö az Észak-alföldi régióban. Az egy före jutó GDP az országos átlagnak mindössze $68 \%$-a, ezzel az országban az utolsó helyen áll. 


\section{Az Észak-alföldi régió helye Európában és Magyarországon}



Forrás: www.eszakalfold.hu

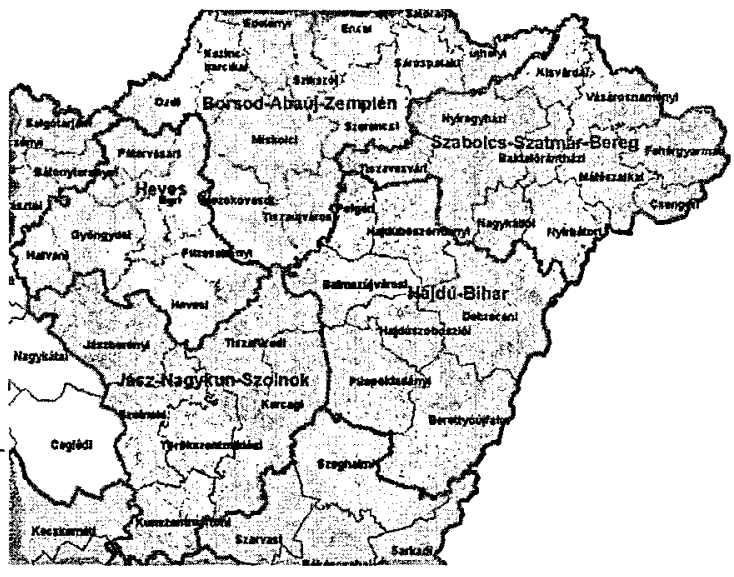

Forrás: www.oth.gov.hu

A területfejlesztésben tevékenykedő szakemberek számára tehát egyfelöl komoly lehetőségeket, másfelöl viszont igen nagy kihívásokat és számtalan nehézséget tartogat a régió. A problémák forrását nem pusztán a térségre jellemző és fentebb vázolt szélsőségek jelentik, hanem az igen eröteljes belsö heterogenitás is. A nagy kiterjedésü, sok tekintetben rokon, de jelentős mértékben eltérő területi egységekkel, természeti és gazdaságföldrajzi térségekkel, illetve a történelmi, sajátos táji, termelési, kulturális hagyományokkal rendelkező régiót ugyanis komoly belső ellentétek jellemzik. ${ }^{8}$

A különböző érdekcsoportok között megfigyelhető szembenállás következményeként jellemző módon az országban utolsóként megalakult Észak-alföldi régió feladatai, hatásköre, valamint rendelkezésre álló pénzügyi forrásai sok esetben még a közigazgatási szervezet magasabb pozícióban lévő vezetői számára sem tisztázottak. A belső kohézió hiánya több esetben ölt formát látványosan, pl. Debrecen és Nyíregyháza versengésében, vagy akár Jász-Nagykun-Szolnok (JNSz) sajátos térszerkezetében. A megyén belüli igen éles területi különbségek hátterében többek között azt a tényt kell keresnünk, hogy az 1876-ban létrehozott - és a lakosság, valamint az országgyülési képviselők körében már ekkor „muszáj-vármegyének” (Balcsók 2004) titulált - megye évszázados területi identitással rendelkező közigazgatási egységekből (Jászság, Nagykunság) állt össze. Emellett a Tiszától keletre fekvő területek az Észak-alföldi régió sajátosságait hordozzák magukon, míg a Tiszától nyugatra már kézzelfoghatóvá válik Budapest erős vonzása.

Mindezeket figyelembe véve talán nem merészség kijelenteni, hogy a sokszinü, az élet szinte minden szegmensét tekintve igen éles területi különbségekkel jellemezhető régióban az alapvetöen közös célok (a régió felzárkóztatása, versenyképessé tétele stb.) ellenére a területfejlesztésben tevékenykedő szakemberek között sem zökkenőmentes az együttmüködés. Igaz ugyan, hogy az EU által müködtetett támogatási rendszer az adott 
térségek területfejlesztési szereplöit az érdemi együttmüködésre ösztönzi, ugyanakkor versenyhelyzetet is teremt közöttük. Az általunk lefolytatott vizsgálat során többek között éppen arra kerestük a választ, hogy az Észak-alföldi régióban a széthúzás vagy az összetartás bizonyul-e erősebbnek az érintett szervezetek és intézmények körében. Tapasztalatainkat az alábbiakban foglaljuk össze.

\section{Fỏbb regionális problémák}

A kérdöívben az általános kérdések után először arra kérdeztünk rá, hogy az intézmények hogyan látják a régióban megjelenő problémákat. Ez a kérdés azért volt fontos, mert rámutatott, hogy a regionális problémák közül a szereplők melyeket tartják hangsúlyosnak, és láthatóvá váltak azok a hatóerök, amelyek az egyes intézményi csoportokat mozgatják. Az azonos problémákat hangsúlyozó csoportok érdekei egybeesnek, ami egyik mutatója lehet a partnerkeresésük irányának. Ezt majd a következő kérdéskör taglalja.

A megkérdezett szereplők a régió problémáit illetően nagy általánosságban ugyanazokat a pontokat említették. Demográfiai problémaként a régió alacsony népességmegtartó erejét, az elöregedést és a képzettek elvándorlását, a hátrányos helyzetü roma népesség magas arányát emelték ki, szociogazdasági problémaként pedig a magas és kedvezőtlen szerkezetü munkanélküliséget, valamint a vállalkozói kedv, tőke és befektetések hiányát. A szabolcs-szatmár-bereg $(\mathrm{SzSzB})$ megyei megkérdezett intézmények nagyobb arányban említették az agrárium problémáit, valamint a munkanélküliség és a termelés kedvezőtlen szerkezetét is. E problémákat összefoglaltuk a régió helyzetéről készített SWOT táblázatban (lásd a függelékben).

A régió infrastruktúráját és környezetvédelmét értékelve a megkérdezettek fỏleg az egyensúlytalanságokat emelték ki. A közlekedési infrastruktúra javult, de ezt főként a Hajdú-Bihar (HB) és SzSzB megye központjai és a nagyobb városok érzékelik, míg a periférikus fekvésü, távoli települések elérhetősége és a közutak minősége nagyon rossz - vélik az érintettek. A JNSz megyéhez tartozó interjúalanyaink említették az autópálya hiányát, ami szerintük regionális konfliktusok forrása is egyben. A szennyvízkezelési és a hulladéktárolási nehézségeket is a legtöbben a problémák közé sorolták. Az árvízvédelmi kérdéseket szintén a JNSz megyei érintettek emelték ki, de a Tisza szennyezettségét már $\mathrm{SzSzB}$-ben is jelentős problémának látják. Itt az ivóvíz minőségét említették az átlagnál többször.

A régióban szembetünő konfliktusokra is rákérdeztünk. A válaszokból kitünt az, amit már a régió bemutatásánál említettünk, miszerint az Észak-alföldi régiót alkotó 3 megye nehezen tud a közös régióban mint egységben gondolkodni. A legtöbben ennél a kérdésnél felvetették a régió hajdani kialakításánál zajló vitákat, amit, úgy tünik, azóta sem tudtak feldolgozni az Észak-alföldi régióban működő intézmények. Êrdekbeli konfliktusok és alkalmazkodási problémák említésénél gyakorta merült fel a megyék közti ellentéten kívül a megyeközpontok, főként Debrecen és Nyíragyháza versengése, valamint a minisztériumok és önkormányzatok közti hatásköri problémák, illetve a régió és a megyék hatásköri megosztásában jelen lévő nehézségek témája. Egyesek kiemelték a „lopakodó regionalizáció" jelenségét, ami éppen ezen utóbbi konfliktusnak köszönhető. Mivel a megyék nem hajlandók elfogadni a régióra egyre inkább átruházott jogköröket, ezért tiszta és átlátható közigazgatási reform helyett egy homályos és lassú felülről vezé- 
relt regionalizáció ${ }^{9}$ történik. Az erőforrások elosztásában lévő konfliktusoknál a megkérdezettek közel fele említette Debrecen, illetve Budapest elszívó hatását, és elhangzott a külföldi lehetöségek elszívó hatása is. Szabolcsban kiemelték a hagyományok erős jelenlétét, ami egyben jelentheti az újításokkal, tanulással való szembenállást is. Ennél a kérdésnél is a minta legalább fele említette a képzési rendszer és a munkaerő-piaci kereslet közti strukturális eltérést.

A regionális problémákat vizsgálva kirajzolódtak azok a főbb területek, amelyekről egyformán gondolkodnak a regionális fejlesztésben érintett szervek. A „hivatalos" regionális problémákkal - amelyet ehelyütt a statisztikai adatokat és komoly háttérelemzést felhasználó Essak-alföldi régió helyzetfeltárására (2003) alapozunk - a megkérdezettek által említett problémák egybeesnek, tehát egyértelmü, hogy a szereplők reálisan látják régiójuk helyzetét. A közel azonos problémát említőket három csoportba lehet sorolni. A csoportok véleménye csak apró eltéréseket mutat a föbb problémák értékelésében, az eltérések pedig egyértelmủen a megyék adottságainak eltéréseit tükrözik.

\section{Regionális hálózatok}

A következőkben megvizsgáltuk a regionális hálózatok jelenlétét, így azt egybe tudtuk vetni az azonos problémákkal rendelkező intézmények partnerkeresési stratégiáinak feltérképezésénél. A régióban jelenlévő hálózatok felrajzolásakor a mintában szereplő résztvevők közti kapcsolatok sürüségére és koncentráltságára fókuszáltunk, és az itt következők csak a regionális szint alatti 26 szereplöre vonatkoznak.

A Társadalmi Kapcsolatháló Elemzés (Borgatti et al 2002) a résztvevők kapcsolati hálóba való beágyazottságára koncentrál, ezért az intézmények, vállalatok, szervezetek mérete nem jelenik meg az input mátrixokban, tehát konzekvensen jelentéktelen marad a számítógépes adatfeldolgozás során az, hogy az adott érintett kis-, közepes vagy nagyméretü szervezet.

Az interjúalanyaink közti kapcsolatok leírására két mátrixot alkottunk:

- Először egy dichotomizált szomszédsági (binary adjacecy) A mátrixot használtunk. A bevitt adatok a következőt jelentik: I (sor) és J (oszlop) érintett közti kapcsolat létezik (1), ha legalább az egyikïk azt állította, hogy müködik a kapcsolat. Ha I és J közül egyik sem említette a kapcsolatot, akkor az érték (0).

- Másodszor egy (a kapcsolati erősségekkel) súlyozott szomszédsági (valued adjacency) B mátrixot alkottunk, melyben az értékek I és J által adott alábbi értékelések felfelé kerekített átlagaiból származnak:

$\Rightarrow(0)$ jelenti, ha nincsen kapcsolat I (sor) és J (oszlop) érintett között,

$\Rightarrow$ (1) jelenti, ha gyenge, informális kapcsolat van alkalmankénti interakciókkal,

$\Rightarrow$ (2) jelenti a közepes erősségü kapcsolatot, pl. formalizált kapcsolat létezik, de az intézményeknek nincsen közös projektjük,

$\Rightarrow$ és a (3) érték pedig erös kapcsolat jelenlétét jelöli a két érintett között, pl. formalizált kapcsolat közös projekttel és rendszeres kapcsolattal.

'A 'regionalizáció egy felülröl induló top-down régiókialakitási mechanizmus szemben a 'regionalizmus' alulról induló régiószervezödésével (Horváth 2003; Süli - Zakar 2003). Az itt emlitett "lopakodó regionalizáció" jelensége egyébként megegyezik a Pálné (1999:238-244) által "erös területfejlesztési régiók - erös megyei területfejlesztési tanácsok - átalakuló kistérségek" néven említett területi közigazgatási jövőképpel. 
Például, ha J szerint a kapcsolata I-vel (1), I szerint pedig (2), akkor mindkét érték I,J és J,I a B mátrixban egyenlö 2-vel, a 1,5-es érték felfelé kerekített értékével. Itt érdemes megjegyezni, hogy mindkét mátrix szimmetrikus, pedig a kapcsolatokat a szereplők általában eltérően értékelték. A korábbi rövidítéseket használva A és B mátrix a következő:

1. tábázat

\section{Az Észak-alföldi régió regionális politikájában érintett résztvevők} közti kapcsolat létezése (Bináris szomszédsági A mátrix a Társadalmi Kapcsolatháló Elemzéshez)

\begin{tabular}{|c|c|c|c|c|c|c|c|c|c|c|c|c|c|c|c|c|c|c|c|c|c|c|c|c|c|c|}
\hline & 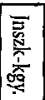 & 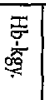 & 急 & 叒 & 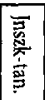 & 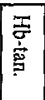 & 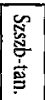 & 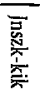 & 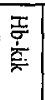 & 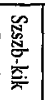 & 돌 & 焉 & 品 & 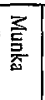 & 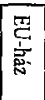 & $\frac{\mathscr{\delta}}{9}$ & : & 妾 & 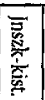 & 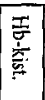 & 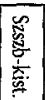 &  & 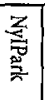 & 胥 &  & 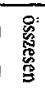 \\
\hline Jnszk- & & 1 & 1 & 1 & 1 & 1 & 1 & 1 & 1 & 1 & 0 & 1 & 1 & 1 & 0 & 1 & 1 & 0 & 1 & 1 & 1 & 1 & 1 & 1 & 0 & 20 \\
\hline $\mathrm{Hb}-\mathrm{kgy}$. & 1 & & 1 & 1 & 0 & 1 & 1 & 0 & 1 & 0 & 1 & 1 & 1 & 1 & 1 & 1 & I & 1 & 0 & 1 & 0 & 1 & 1 & 1 & 1 & P \\
\hline Szszb-kgy. & 1 & 1 & & 1 & 1 & 1 & 1 & 0 & 0 & 1 & 1 & 1 & 1 & 1 & 1 & 1 & 1 & 1 & 0 & 0 & 1 & 0 & 1 & 1 & 1 & 19 \\
\hline RFT & 1 & 1 & 1 & & 1 & 1 & 1 & 1 & 1 & 1 & 1 & 1 & 1 & 1 & 1 & 1 & 1 & 1 & 1 & 1 & 1 & 1 & 1 & 1 & 1 & 24 \\
\hline Jnszk-tan. & 1 & 0 & 1 & 1 & & 1 & 1 & 1 & 0 & 0 & 0 & 1 & 1 & 1 & 0 & 1 & 0 & 0 & 1 & 0 & 0 & 0 & 0 & 0 & 1 & 12 \\
\hline Hb-tan. & 1 & 1 & 1 & 1 & 1 & & 1 & 0 & 1 & 0 & 1 & 1 & 1 & 1 & 1 & 0 & 1 & 0 & 0 & 1 & 0 & 1 & 1 & 1 & 1 & 18 \\
\hline Szszb-tan. & 1 & 1 & 1 & 1 & 1 & 1 & & 0 & 0 & 1 & 1 & 1 & 1 & 1 & 0 & 0 & 0 & 1 & 0 & 0 & 1 & 0 & 1 & 1 & 1 & 16 \\
\hline Jnszk-kik & 1 & 0 & 0 & 1 & 1 & 0 & 0 & & 1 & 1 & 1 & 1 & 1 & 1 & 0 & 1 & 0 & 0 & 1 & 0 & 0 & 0 & 0 & 1 & 3 & 13 \\
\hline Hb-kik & 1 & 1 & 0 & 1 & 0 & 1 & 0 & 1 & & 1 & 1 & 1 & 3 & 1 & 1 & 0 & 1 & 0 & 0 & ] & 0 & 1 & 0 & 1 & 1 & 16 \\
\hline Szszbb-kij & 1 & 0 & 1 & 1 & 0 & 0 & 1 & 1 & 1 & & 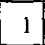 & 1 & 1 & 1 & 0 & 0 & 0 & 1 & 0 & 0 & 1 & 0 & 1 & 1 & 1 & 15 \\
\hline Univ & 0 & 1 & 1 & 1 & 0 & 1 & 1 & 1 & 1 & 1 & & 1 & 1 & 1 & 1 & 1 & 1 & 1 & 0 & 1 & 1 & 0 & 1 & 1 & 1 & 20 \\
\hline Ügyn & 1 & 1 & 1 & 1 & 1 & 1 & 1 & 1 & 1 & 1 & 1 & & 1 & 1 & 1 & 1 & 1 & 1 & 1 & 1 & 1 & 1 & 4 & 1 & ] & 24 \\
\hline Bank & 1 & 1 & 1 & 1 & 1 & 1 & 1 & 1 & 1 & 1 & 1 & 1 & & 1 & 1 & 1 & 1 & 1 & 1 & 1 & 1 & 1 & 1 & 0 & 0 & 22 \\
\hline Munk & 1 & 1 & 1 & 1 & 1 & 1 & 1 & 1 & 1 & 1 & 1 & 1 & 1 & & 1 & 1 & 1 & 1 & 1 & 1 & 1 & 1 & 1 & 1 & 1 & 24 \\
\hline EU-ház & 0 & 1 & 1 & 1 & 0 & 1 & 0 & 0 & 1 & 0 & 1 & 1 & 1 & 1 & & 0 & I & 0 & 0 & 1 & 0 & 1 & 1 & 1 & 1 & 15 \\
\hline Szoln & 1 & 1 & 1 & 1 & 1 & 0 & 0 & 1 & 0 & 0 & 1 & 1 & 1 & 1 & 0 & & 1 & 1 & 1 & 0 & 0 & 0 & 0 & 0 & 1 & 14 \\
\hline Debr & 1 & 1 & 1 & 1 & 0 & 1 & 0 & 0 & 1 & 0 & 1 & 1 & 1 & 1 & 1 & 1 & & 1 & 0 & 1 & 0 & 1 & 1 & 1 & 1 & 18 \\
\hline Nyíre & 0 & 1 & 1 & 1 & 0 & 0 & 1 & 0 & 0 & 1 & 1 & 1 & 1 & 1 & 0 & 1 & 1 & & 0 & 0 & 1 & 0 & 1 & 1 & 1 & 15 \\
\hline Inszk-kist. & 1 & 0 & 0 & 1 & 1 & 0 & 0 & 1 & 0 & 0 & 0 & 1 & 1 & 1 & 0 & 1 & 0 & 0 & & 1 & 1 & 0 & 0 & 1 & 1 & 12 \\
\hline Hb-kist. & 1 & 1 & 0 & 1 & 0 & 1 & 0 & 0 & 1 & 0 & 1 & 1 & 1 & 1 & 1 & 0 & 1 & 0 & 1 & & 1 & 0 & 0 & 1 & 1 & 15 \\
\hline Szszb-kist. & 1 & 0 & 1 & 1 & 0 & 0 & 1 & 0 & 0 & 1 & 1 & 1 & 1 & 1 & 0 & 0 & 0 & 1 & 1 & 1 & & 0 & 1 & 1 & 1 & 15 \\
\hline DIPark & 1 & 1 & 0 & 1 & 0 & 1 & 0 & 0 & 1 & 0 & 0 & 1 & 1 & 1 & 1 & 0 & 1 & 0 & 0 & 0 & 0 & & 1 & 1 & 0 & 12 \\
\hline NyIPark & 1 & 1 & 1 & 1 & 0 & 1 & 1 & 0 & 0 & 1 & 1 & 1 & 1 & 1 & 1 & 0 & 1 & 1 & 0 & 0 & 1 & 1 & & 0 & 1 & 17 \\
\hline RKK & 1 & 1 & 1 & 1 & 0 & 1 & 1 & 1 & 1 & 1 & I & 1 & 0 & 1 & 1 & 0 & 1 & 1 & 1 & 1 & 1 & 1 & 0 & & 1 & 20 \\
\hline Cégek & 0 & 1 & 1 & 1 & 1 & 1 & 1 & 1 & 1 & 1 & 1 & 1 & 0 & 1 & 1 & 1 & 1 & 1 & 1 & 1 & 1 & 0 & 1 & 1 & & 21 \\
\hline összesen & 20 & 19 & 19 & 24 & 12 & 18 & 16 & 13 & 16 & 15 & 20 & 24 & 22 & 24 & 15 & 14 & 18 & 15 & 12 & 15 & 15 & 12 & 17 & 20 & $2 \mathrm{I}$ & 436 \\
\hline
\end{tabular}

Forrás: Saját szerkesztés a kérdőives felmérés alapján 
2. táblázat

Az Észak-alföldi régió regionális politikájában érintett résztvevők közti kapcsolat erőssége

(Súlyozott szomszédsági B mátrix a Társadalmi Kapcsolatháló Elemzéshez)

\begin{tabular}{|c|c|c|c|c|c|c|c|c|c|c|c|c|c|c|c|c|c|c|c|c|c|c|c|c|c|c|}
\hline & 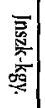 & 丞 & 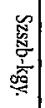 & 莺 & $\begin{array}{l}\overline{\bar{B}} \\
\frac{\sqrt[3]{5}}{\bar{t}} \\
\bar{g}\end{array}$ & 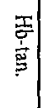 & 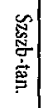 & 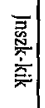 & 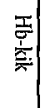 & 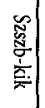 & $\stackrel{5}{\Xi}$ & $\stackrel{g}{\circ}$ & 急 & 忞 & 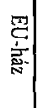 & $\stackrel{8}{5}$ & 品 & ż. & 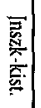 & 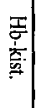 & 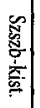 & $\begin{array}{l}\text { 목 } \\
\text { 究 }\end{array}$ & 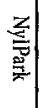 & 줒 & 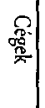 & 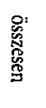 \\
\hline Inszk-kgy. & & 1. & 1 & 2 & 2 & 1 & 1 & 3 & 2 & 2 & 0 & 1 & 1 & 1 & 0 & 2 & 1 & 0 & 2 & 1 & 1 & 1 & 1 & 1 & 0 & 28 \\
\hline $\mathrm{Hb}-\mathrm{kgy}$ & 1 & & 2 & 3 & 0 & 3 & 3 & 0 & 3 & 0 & 2 & 2 & 1 & 3 & 3 & 1 & 3 & 1 & 0 & 3 & 0 & 1 & 1 & 2 & 3 & $4 \mathrm{I}$ \\
\hline Szszb-kgy. & 1 & 2 & & 3 & 2 & 2 & 3 & 0 & 0 & 3 & 1 & 2 & 1 & 2 & 1 & 1 & 1 & 3 & 0 & 0 & 2 & 0 & 3 & 1 & 2 & 36 \\
\hline RFT & 2 & 3 & 3 & & 3 & 3 & 3 & 2 & 2 & 2 & 2 & 3 & 1 & 3 & 1 & 3 & 3 & 3 & 2 & 3 & 2 & 1 & 1 & 1 & 1 & 53 \\
\hline Inszk-tan. & 2 & 0 & 2 & 3 & & 3 & 3 & 2 & 0 & 0 & 0 & 3 & 1 & 1 & 0 & 3 & 0 & 0 & 2 & 0 & 0 & 0 & 0 & 0 & 1 & 26 \\
\hline Hb-tan. & 1 & 3 & 2 & 3 & 3 & & 2 & 0 & 2 & 0 & 1 & 3 & 1 & 2 & 1 & 0 & 3 & 0 & 0 & 2 & 0 & 1 & 1 & 1 & 2 & 34 \\
\hline Szszb-tan. & 1 & 3 & 3 & 3 & 3 & 2 & & 0 & 0 & 2 & 1 & 3 & 1 & 2 & 0 & 0 & 0 & 3 & 0 & 0 & 3 & 0 & 2 & 2 & 2 & 36 \\
\hline Inszk-kik & 3 & 0 & 0 & 2 & 2 & 0 & 0 & & 3 & 3 & 1 & 2 & 2 & 2 & 0 & 2 & 0 & 0 & 1 & 0 & 0 & 0 & 0 & 1 & 1 & 25 \\
\hline Hb-kik & 2 & 3 & 0 & 2 & 0 & 2 & 0 & 3 & & 3 & 2 & 2 & $1)$ & 2 & 3 & 0 & 2 & 0 & 0 & 2 & 0 & 1 & 0 & 2 & 2 & 34 \\
\hline Szszb-kik & 2 & 0 & 3 & 2 & 0 & 0 & 2 & 3 & 3 & & 1 & 2 & 2 & 3 & 0 & 0 & 0 & 2 & 0 & 0 & 2 & 0 & 2 & 1 & 2 & 32 \\
\hline Univ & 0 & 2 & 1 & 2 & 0 & 1 & 1 & 1 & 2 & 1 & & 2 & 1 & 1 & 2 & 1 & 3 & 2 & 0 & 1 & 1 & 0 & 1 & 1 & 2 & 29 \\
\hline Ügyn. & 1 & 2 & 2 & 3 & 3 & 3 & 3 & 2 & 2 & 2 & 2 & & 1 & 2 & 2 & 3 & 3 & 3 & 2 & 2 & 2 & 2 & 2 & 3 & 3 & 55 \\
\hline Bank & 1 & 1 & 1 & 1 & 1 & 1 & 1 & 2 & 1 & 2 & 1 & 1 & & 1 & 1 & 1 & 1 & 1 & 1 & 1 & 1 & 1 & 1 & 0 & 0 & 24 \\
\hline Munka & 1 & 3 & 2 & 3 & 1 & 2 & 2 & 2 & 2 & 3 & 1 & 2 & 1 & & 2 & 2 & 2 & 2 & 2 & 2 & 2 & 2 & 2 & 2 & 2 & 47 \\
\hline EU-ház & 0 & 3 & 1 & 1 & 0 & 1 & 0 & 0 & 3 & 0 & 2 & 2 & 1 & 2 & & 0 & 3 & 0 & 0 & 1 & 0 & 2 & 1 & 2 & 2 & 27 \\
\hline Szoln & 2 & 1 & 1 & 3 & 3 & 0 & 0 & 2 & 0 & 0 & 1 & 3 & 1 & 2 & 0 & & 1 & 1 & 2 & 0 & 0 & 0 & 0 & 0 & 1 & 24 \\
\hline Debr & 1 & 3 & 1 & 3 & 0 & 3 & 0 & 0 & 21 & 0 & 3 & 3 & 1 & 2 & 3 & 1 & & 1 & 0 & 1 & 0 & 2 & 2 & 2 & 2 & 36 \\
\hline Nyíre & 0 & 1 & 3 & 3 & 0 & 0 & 3 & 0 & 0 & 2 & 2 & 3 & 1 & 2 & 0 & 1 & 1 & & 0 & 0 & 3 & 0 & 3 & 1 & 1 & 30 \\
\hline Inszk-kist. & 2 & 0 & 0 & 2 & 2 & 0 & 0 & 1 & 0 & 0 & 0 & 2 & 1 & 2 & 0 & 2 & 0 & 0 & & 1 & 1 & 0 & 0 & 1 & 2 & 19 \\
\hline Hb-kist. & $1]$ & 3 & 0 & 3 & 0 & 2 & 0 & 0 & 2 & 0 & 1 & 2 & 1 & 2 & 1 & 0 & 1 & 0 & 1 & & 1 & 0 & 0 & 1 & 2 & 24 \\
\hline Szszb-kist. & 1 & 0 & 2 & 2 & 0 & 0 & 3 & 0 & 0 & 2 & 1 & 2 & 1 & 2 & 0 & 0 & 0 & 3 & 1 & 1 & & 0 & 2 & 2 & 2 & 27 \\
\hline DIPark & 1 & 1 & 0 & 1 & 0 & 1 & 0 & 0 & 1 & 0 & 0 & 2 & 1 & 2 & 2 & 0 & 2 & 0 & 0 & 0 & 0 & & 1 & 1 & 0 & 16 \\
\hline NyIPark & 1 & 1 & 3 & 1 & 0 & 1 & 2 & 0 & 0 & 2 & 1 & 2 & 1 & 2 & 1 & 0 & 2 & 3 & 0 & 0 & 2 & 1 & & 0 & 2 & 28 \\
\hline $\mathrm{RKK}$ & 1 & 2 & 1 & 1 & 0 & 1 & 2 & 1 & 2 & 1 & 1 & 3 & 0 & 2 & 2 & 0 & 2 & 1 & 1 & 1 & 2 & 1 & 0 & & 2 & 30 \\
\hline Cégek & 0 & 3 & 2 & 1 & 1 & 2 & 2 & 1 & 2 & 2 & 2 & 3 & 0 & 2 & 2 & 1 & 2 & 1 & 2 & 2 & 2 & 0 & 2 & 2 & & 39 \\
\hline összesen & 28 & 41 & 36 & 53 & 26 & 34 & 36 & 25 & 34 & 32 & 29 & 55 & 24 & 47 & 27 & 24 & 36 & 30 & 19 & 24 & 27 & 16 & 28 & 30 & 39 & 800 \\
\hline
\end{tabular}

Forrás: Saját szerkesztés a kérdőives felmérés alapján

A politikai hálózatok fontos jellemzője a sürüség. A hálózat alacsony sủrủsége azt jelenti, hogy a szereplők közti kapcsolatok alapvetően gyengék.

- Módszer: A bináris hálózatok sürüsége az összes létező kapcsolat száma elosztva az összes lehetséges kapcsolattal.

- Eredmény: A megfigyelt bináris hálózat sürüségének értéke: 0.7267 . Ez az érték azt jelenti, hogy a vizsgált hálózatban a lehetséges kapcsolatoknak több mint $70 \%$-a létezik, legalább az egyik irányban. 
- Módszer: A súlyozott hálózatban a sürüség az összes súly osztva a lehetséges kapcsolatok számával. Ebben az esetben a sürüség az átlagos értéket adja.

- Eredmény: A vizsgált értékkel súlyozott hálózat sürüsége: 1.3367. Ez az érték a következőképpen értelmezhető: A létező kapcsolatok átlagos erőssége 1,839 ami azt mutatja, hogy a létező kapcsolatok nagyobb része inkább gyenge és közepes szinten müködik.

A centralitás jelzőszám feladata, hogy feltárja minden egyes érintett beágyazottságának mértékét a kapcsolati hálóban. A centralitás fokának mérésére a Freeman-módszert alkalmaztuk a szimmetrikus hálózatra. A diagonális kapcsolatokat (az adott intézmények önmagukkal vett kapcsolata) nem vettük érvényesnek. Ahogy vártuk, a centralizáció nem egyenletesen oszlik meg a szereplök csoportjai közt. A legnagyobb centralitási fokkal szervezetek a regionális fejlesztési tanács és a regionális fejlesztési ügynökség, a legkisebbel pedig a kistérségek és helyi szervezetek rendelkeznek ${ }^{10}$. Ezek az eredmények mind a bináris, mind a súlyozott esetben ugyanúgy érvényesek. Érdemes megfigyelni, hogy a régióközpont Debrecen helye valóban centrálisabb, mint Nyíregyháza vagy Szolnok szerepe.

3. táblázat

\section{Centralitási méröszámok a bináris szomszédsági mátrix esetében}

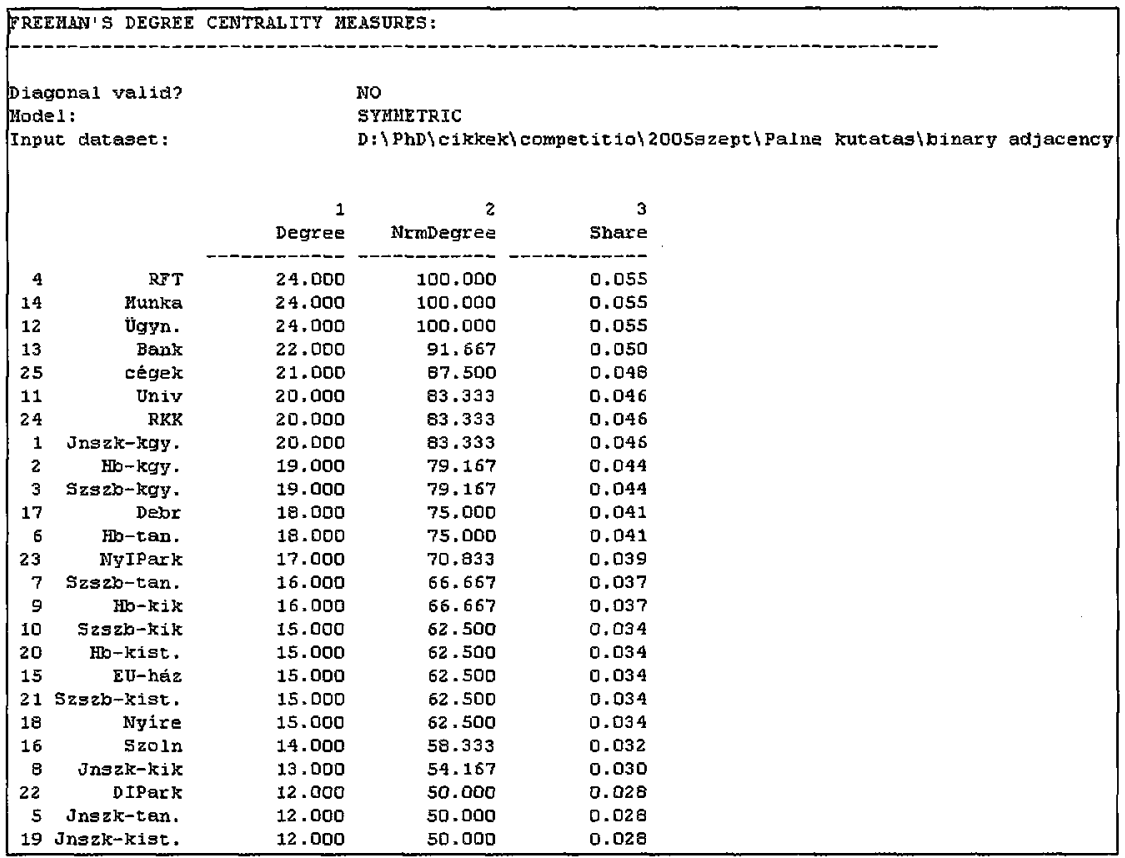

10 Az adatokból úgy tünhet, hogy a munkaügyi központok szerepe is központi elhelyezkedésü. Ez azonban annak a mintavételi hibának az eredménye, hogy nem nevesitettük öket megyénként. Ez torzitotta az eredményeinket. 
4. táblázat

Centralitási mérőszámok a súlyozott szomszédsági mátrix esetében

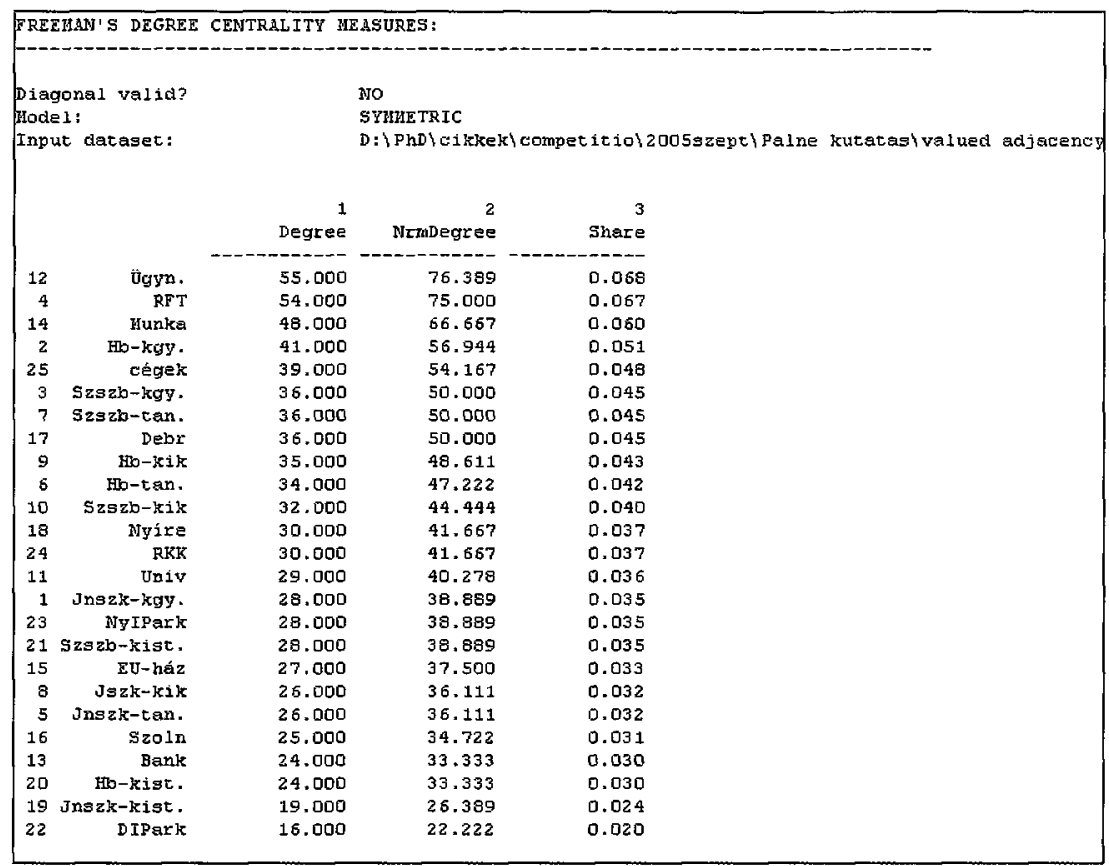

A multi-dimenzionális skálázás módszere az intézményi hálózatok esetében. A multidimenzionális skálázás (MDS) módszer célja, hogy a vizsgált hálózatról kétdimenziós képet alkothassunk. Az algoritmus úgy mủködik, hogy minden egyes szereplönek keres egy helyet a síkban ${ }^{11}$, az egyes szereplők közti távolság pedig arányos az adott szereplők közti kapcsolat erősségével. Ez a módszer jól alkalmazható a szereplök centrum- illetve periférikus helyzetének érzékeltetésére. A bináris és a súlyozott szomszédsági mátrixokból adódó eredmény: mindkét ábra lehetővé teszi, hogy jól elkülöníthessük a központi és a periférikus szereplőket.

Központban elhelyezkedő szereplök. Ahogy számítottunk is rá, mindkét mátrixban (akár a bináris, akár a súlyozott esetet vizsgáljuk is) a következő szereplők foglalják el a központi helyeket a MDS gráfban:

- Regionális Fejlesztési Ügynökség,

- Regionális Fejlesztési Tanács,

- a Magyar Fejlesztési Bank és a

- pályázatíró cégek.

A perifériára szorult szereplők a kistérségi társulások, az ipari parkok, az Euro-Régió Ház Kht. De ami igazán jól látható ezen a képen, az a periféria elkülönülése, három

" A számítógép adta lehetöségeknek köszönhetöen háromdimenziós képet is készithetünk a hálózatról, ezt persze a nyomtatott forma nem adja vissza. 
részre válása, megyék köré csoportosulása. Debrecen (mint a hálózati rajz perifériáján található szereplö) köré a Hajdú-Bihar Megyei Területfejlesztési Tanács, a HB Megyei Közgyülés, a Kereskedelmi és Ipar Kamara, valamint a Debreceni Ipari Park, és ugyanígy Nyíregyháza köré pedig a SzSzB megyei intézmények és szervezetek csoportosulnak.

\section{A multi-dimenzionális skálázás diagramja a súlyozott szomszédsági mátrix esetében}

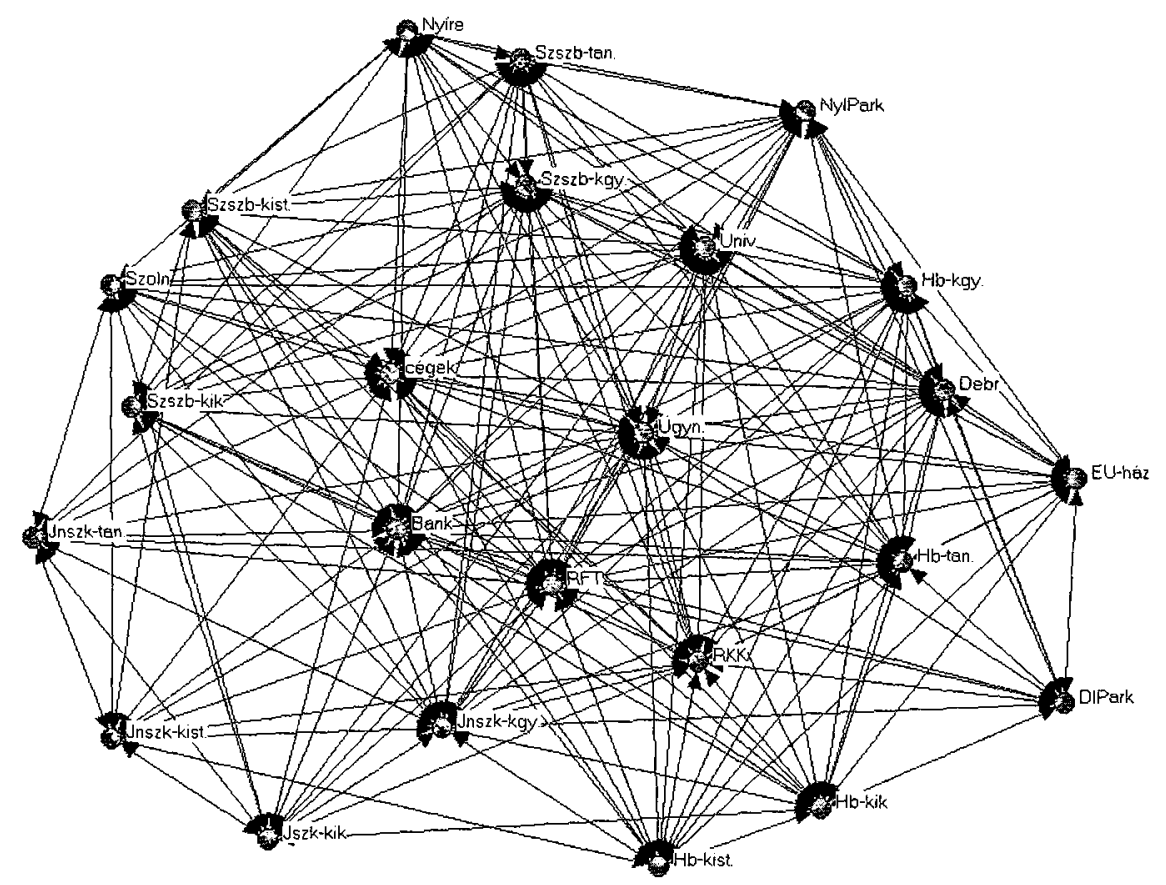

Forrás: Saját szerkesztés a kérdöives felmérés adataiból az UCINET szoftver segitségével

A régióban a regionális politika terén jelenlévő hálózatokról összefoglalóan tehát a következőt lehet elmondani: A hálózat viszonylag sürünek mondható, 100 lehetséges kapcsolatból 72 létezik. A kapcsolatok átlagos erössége $(1,839)$ azt mutatja, hogy a létező kapcsolatok nagyobb része közepes szinten müködik. Ez az érték azonban jóval erösebb, mint a Dél-dunántúli régióban mért 0,4-es érték, és megközelíti az ír (Mid-West) régióban tapasztaltakat (Getimis 2003).

Bár az általunk vizsgált régióban a magánszektor és a civil szervezetek is a hálózat részét képezik, a domináns szerepet a közigazgatási szervek játsszák. A regionális szintü szervekkel való kapcsolatok erössége egyre jelentősebb, és közelít a nemzeti szint arányaihoz. A megyén belüli szereplök közti kapcsolatok erősebbek, mint a megyék közötti. Érdemes megemlíteni, hogy a mátrixba bevitt számadatok olyan kapcsolatokat fednek el sokszor, amelyek intézményesítettek (tehát valamilyen megállapodásban, esetleg jogszabályban rögzítettek), mégis, ennek ellenére csak az informális kapcsolat erősségét 
érik el. A látszatkapcsolatok, illetve protokollkapcsolatok jelenlétét tehát csak az adatok mögé nézve érhetjük tetten.

A hálózat centralizációs foka 103\%. Központi szerepet a Regionális Fejlesztési Ügynökség és a Regionális Fejlesztési Tanács játszik. Ez a forráselosztás központi természetével is magyarázható, amelyet a regionális politikai döntések centralizáltsága, a szabályozási rendszer és a pályázati rendszer szintén centralizált jellege támaszt alá. Ezekben a helyi, települési szintü résztvevök szerepe nagyon korlátozott. Összehasonlításként az ADAPT program centralitási méröszámai a Dél-dunántúli régióban $56 \%$ (ez volt a legalacsonyabb a vizsgált esetek közül), a portugál régió esetében $105 \%$, míg az ír esetben 137\% (Getimis 2003:20).

Vizsgálatunk során a legerősebb kapcsolati hálót a hasonló profilú, illetve szakterületű intézmények közt találtunk, de csak megyén belüli léptékben, és jól kimutatható a személyes kapcsolatok jelentôsége. A hálózaton belül jól elkülöníthettük a megyén belïli kapcsolatokat. A partnerségi hálózatokat megyén túli, de régió alatti szinten inkább versenytársi viszony helyettesíti, ahogy az a regionális konfliktusoknál már említésre került, de régiós szint felett újra könnyebb a partnerségre való törekvések kimutatása.

\section{Régiók közötti, nemzeti és európai hálózatok}

Kérdőívünk következő része a más régiókkal való együttmüködésekre kérdezett rá, legyen az határon belül vagy kívül. A válaszok nagyon szerteágazó kapcsolatokat mutatnak: testvérmegyék és testvérvárosok, eurorégiók és nemzetközi szervezetek, keretmegállapodások és speciális programok, amelyek keretében keresik partnereiket a regionális fejlesztésben érintett szervezetek. Együttmüködések széles skáláját tudtuk lejegyezni. Nem volt olyan megkérdezett, aki nem említett valamilyen kapcsolatot.

A nemzeti vagy országon belüli kapcsolatoknál jellemzően az adott szervezetet tömörítő valamilyen országos szövetségben való részvételt, illetve a többi megyében, régióban múködö azonos intézményekkel fenntartott kapcsolatokat említették. İgy például a városi önkormányzatok a megyei jogú városok, valamint a falvak-városok szövetségét, az agrár-, valamint a kereskedelmi és iparkamarák a kamarai együttmüködéseket, az ipari parkok az ipari parkok egyesületét, a fejlesztési ügynökségek a jó régiók közti kapcsolatokat és együttmüködéseket emelték ki.

$\mathrm{Az}$ országhatáron túlnyúló kapcsolatoknál föleg a HB és SzSzB megyei megkérdezettek válaszaiban volt nagy számban a környező országok magyar lakta megyéiben és régióiban müködő hasonló szervezet megjelölve (bihor, szatmár, harghita, máramaros és arad megyei kamarákkal, kárpátaljai önkormányzatokkal és civilszolgáltató-központokkal való együttmúködések). A Kárpátok Eurorégión belüli együttmüködést a megkérdezettek több mint egyharmada említette, de szóba került a Bihar-Bihor és a Duna-Kőrös-Maros Eurorégió is. Távolabbra nyúló kapcsolatokat a testvérvárosi, testvérmegyei és testvérrégiós kapcsolatok jelentenek a régió szervei számára. İgy például a régió testvéri kapcsolatai, melyek az olasz Friuli-Venezia Giulia és Emilia-Romagna régiótól a dél-svéd régióig húzódnak, vagy a JNSz megye 13 megyekapcsolata, amely brit testvértöl lengyel testvérig terjed, de ugyanígy fontos például a nyíregyházi részvétel két testvérvárosi hálózatban (Európai Középvárosok Szövetsége és a CINTE városhálózat), mely 9 testvérvárosi és 5 partnervárosi kapcsolatot jelent. Látható, hogy a skála rend kívül széles. 
Együttmüködési kereten túlmutató konkrét programban vagy projektben való részvételt azonban viszonylag kevesebbszer említettek. Itt a regionális ügynökség programjai, a városok URBAN illetve INTERREG pályázatai, a kistérségi társulások részvétele INTERREG programokban, valamint a pályázatíró cégek és az Euro-Régió Ház piaci alapon való együttmüködési megállapodásai emelhetők ki.

Az elöző fejezetben, ahol a regionális problémák meglátását és a problémákban való osztozást vizsgáltuk, arra lehetett következtetni, hogy az itt talált azonosságok mentén fognak a régió vizsgált szervezetei partnereket keresni maguk mellé. De ahogy ezt az elözőkben láthattuk, nem vázolható fel tiszta stratégia az intézmények partnerkeresésében. A regionális szint nem is partnerségi, hanem versengési színteret jelent. A régiós szintet átlépve azonban burjánzó kapcsolati hálók rajzolódtak ki. Vajon ezt az európai uniós integrációnk kényszerítette ki?

\section{Európai Regionális Politika}

Kérdőívünkben az uniós szintü regionális politikához való viszonyt, az európai szinten való gondolkodást vizsgáló rész több kérdéskört is taglalt. Elöször megkérdeztük, hogy milyen európai uniós programokban vett részt az adott szervezet, majd a programok során felmerült nehézségek felsorolására kértük öket. Megkérdeztük, hogy a programok alakításában volt-e befolyásuk, részt vettek-e a tervezési folyamatban, és, ha igen, milyen szinten. Végül az európai programok jelentőségét és hatásait kellett értékelniük.

Határrégió levén a szereplők legtöbbje Phare CBC és INTERREg programokban való részvételről számolt be. Több pályázat zajlott és zajlik még a Phare, a Humán Erőforrás Fejlesztési Operatív Program és a Regionális Operatív Program valamely prioritása keretében is. Találkoztunk azonban LEADER, V. kutatási keretprogram, valamint Leonardo da Vinci programban való résztvevőkkel is.

A programok során felmerült nehézségek közül az összeütköző érdekek és a késleltetett pénzek problémáját emelték ki legtöbben. Az összeütköző érdekek eredményét egyik interjúalanyunk úgy összegezte, hogy itt érhetô tetten leginkább az „egyenlősíto" és nem pedig a "csak a legrászorultabbakat támogatjuk!" politika megjelenése. A hozzáértés problémáira és az alkalmazottak hiányára rákérdezve többen is úgy fogalmaztak, hogy viszonylag sokan dolgoznak a regionális fejlesztésben, de a gyakorlott szakemberből hiány van. Jellemzően sok a pályakezdö, az idősebb, tapasztaltabb kollégák pedig nehezen vállalják a döntésekkel járó felelősséget. Általánosan jellemző a felkészületlenség - vélik föleg azok, akik a pályázatokat írják -, és megfigyelhető az a jelenség is, hogy az utolsó percben érkezik tájékoztatás arról, hogy megváltoztak a formai vagy tartalmi követelmények. A projektek megvalósítása során a szakmai feladatok és a pénzügyi lebonyolítás túl nagy humánerőt köt le, így inkább a túlzott bürokratizmus terheli meg a pályázót, semmint a projekt kivitelezése.

$\mathrm{Az}$ uniós programok jelentőségét mindannyian fontosnak értékelték, és a vélemények szerint ez a jövőben még nagyobb súlyt fog kapni. „Ez nem csupán az unióból érkező pénzügyi források miatt van így (bár ennek jelentősége kétségtelenül óriási), - véli egyik interjúalanyunk. „A legfontosabb az, hogy elkezdődött egy olyan fajta tervezés és jövőben való gondolkodás, ami korábban nem létezett. Ez pedig hozzásegíthet bennünket a világpiacon való helytálláshoz!" 


\section{Összegzés}

Kutatásunk során a regionális politika terén létező hálózatokat és partnerséget vizsgáltuk az Észak-alföldi régió mintáján. Felmértük a legjelentősebb szereplök által régiójukban legfontosabbnak tartott problémákat. Felmértük problémaérzékelési képességüket. Válaszaikból rajzolódtak ki azok a fó hangsúlyok, amelyek mentén egy regionális partnerségi stratégia kialakulhat. Feltártuk azokat a döntő tényezőket is, amelyek a partnerkeresésre ösztönöznek.

A felmérésből kiderült, hogy föleg ott alakulnak ki a kapcsolatok, ahol a szakterületi profil a leginkább egybevág, de tapasztaltuk a törvényi kényszert is és a protokollkapcsolatok jelenlétét. A kapcsolati háló erőssége a hasonló müködési körü szervezetek közt megyén belül jóval intenzívebb, mint a megyék közt, ami a megyék közt meglévő konfliktusokkal és a forrásokért való versennyel magyarázható. Az EU-integráció által kiváltott alkalmazkodási folyamatok regionális szint alatt intézményi konfliktusokat szülnek, míg országos szinten segítették a kapcsolatok fejlödését.

Az együttmüködések régión túli, országos és európai szintű kialakulását azzal a céllal vizsgáltuk, hogy feltárjuk a fejlesztési politika résztvevői által követett stratégiát, és azt, hogy észak-alföldi szempontból mi motiválja a partnerválasztásukat. Kutatásunk végkövetkeztetése azonban az, hogy ilyen stratégia nem mutatható ki, legfeljebb egyegy jellemző kapcsolattartót tudtunk kitapintani, amely esettanulmányunkban a Regionális Fejlesztési Tanács és a Regionális Fejlesztési Ügynökség szervezete volt.

A történelmi és földrajzi adottságok miatt az Észak-alföldi régió inkább konfliktusokkal terhelt, széthúzó, mint együttmüködő régió. Az eddigi partnerségek és kapcsolatok kialakulása föleg az uniós és magyar törvényi elöírások nyomásának a következménye. Az alacsony szinten, de már érzékelhető társadalmi tőke és a személyes kapcsolatok jelenléte azonban elörevetíti azt az állapotot, amikor a területfejlesztési kezdeményezések már nem felülröl, hanem alulról, az érintettektől indulnak, főként az emberi tényezőnek, az agilis területfejlesztési menedzsereknek köszönhetően.

\section{Hivatkozások}

ADAPT (2003): ADAPT 5th Framework Programme. http://www.lse.ac.uk/collections/hellenicObservatory/ research /adaptIntro.htm. Letöltés idöpontja: 2005. augusztus 10.

Balcsók István (2004): Történelmi, természeti, gazdasági-társadalmi környezet és adottságok. In: Csiszér Z. (föszerk.): Észak-alföldi régió. (Magyarország régiói, 6.) Csiszér Bt., Debrecen, 81146.

Baranyi Béla - Balcsók István - Dancs László (2002): A polgármesterek térségi kötödéstípusainak vizsgálata az Észak-alföldi régióban. Területi Statisztika, 42. sz. 253-270.

Borgatti, S.P., Everett, M.G. és Freeman, I.C. (2002): Ucinet for Windows: Software for Social Network Analysis. Analytic Technologies, Harvard, MA.

Börzel, Tanja (2001): Europeanization and Domestic Institutional Change: Toward Cooperative Regionalism. In: Green, C. - Caporaso, J. - Risse, T. (szerk.): Transforming Europe: Europeanization and Domestic Change. Cornell University Press, Ithaca - London, 137-158.

Futó Péter - Pálné Kovács Ilona - Fleischer Tamás - Dombi Péter (2002): The Evolution of Multi-level Governance in Regional and Environmentl Policies in Hungary. http: //www.vki.hu/ tfleisch/ pdf/pdf03/adapt-hu-final.pdf. Letöltés időpontja: 2005. január 12.

Getimis, Panayiotis (2003): EU Enlargement and Multi-Level Governance in European Regional and Environment Policies: Patterns of Learning, Adaptation and Europeanization among Cohesion Countries (Greece, Ireland and Portugal) and Lessons for New Members (Hungary and Poland). 
http://www. 1se.ac.uk/collections/hellenicObservatory/pdf/ ADAPT.EXECUTIVE_FINAL_ REPORT.pdf Letöltés időpontja: 2005. augusztus 10.

Helyzetfeltárás (2003): Észak-Alföldi Régió területfejlesztési koncepciója és terülletfejlesztési stratégiai programja, valamint operatív programja. Helyzetelemzés. http://earfu.axelero.net/Regios_ doksik/Helyzetfeltaras/EA_helyzetfeltaras_szoveg/EA_helyzetfeltaras.doc

Horváth Gyula (2003): Regionális támogatások az Európai Unióban. Osiris kiadó, Budapest.

Kende Tamás - Szücs Tamás (szerk.) (2003): Európai közjog és politika. Osiris kiadó, Budapest.

Marks, Gery - Hooghe, Liesbet (2004): Contrasting Visions of Multi-level Governance. In: Bache, Ian - Flinders, Matthiew: Multi-level Governance. Oxford University Press, Oxford, 15-30.

Pálné Kovács Ilona (1999): Regionális politika és közigazgatás. Dialóg Campus Kiadó, Budapest Pécs.

Pálné Kovács Ilona (2005): Europeanization and Two Phases of Regionalism in Hungary. Elöadás a Regional Studies Association Regional Growth Agendas címü konferenciáján. http:/www. regional-studies-assoc.ac.uk/events/aalborg05/kovacs.pdf. Letöltés idöpontja: 2005. augusztus 10.

Sutcliffe, John B, (2000): The 1999 Reform of the Structural Fund Regulations: Multi-Level Governance or Renationalization? Journal of European Public Policy, 7. évf. 2, sz. 290-309.

Süli-Zakar István (2003): A terület- és településfejlesztés alapjai. Dialóg Campus Kiadó, Budapest. 


\section{Függelék}

\section{A SWOT elemzés}

\begin{tabular}{|c|c|}
\hline Erŏsségek $^{1213}$ & Gyengeségek \\
\hline 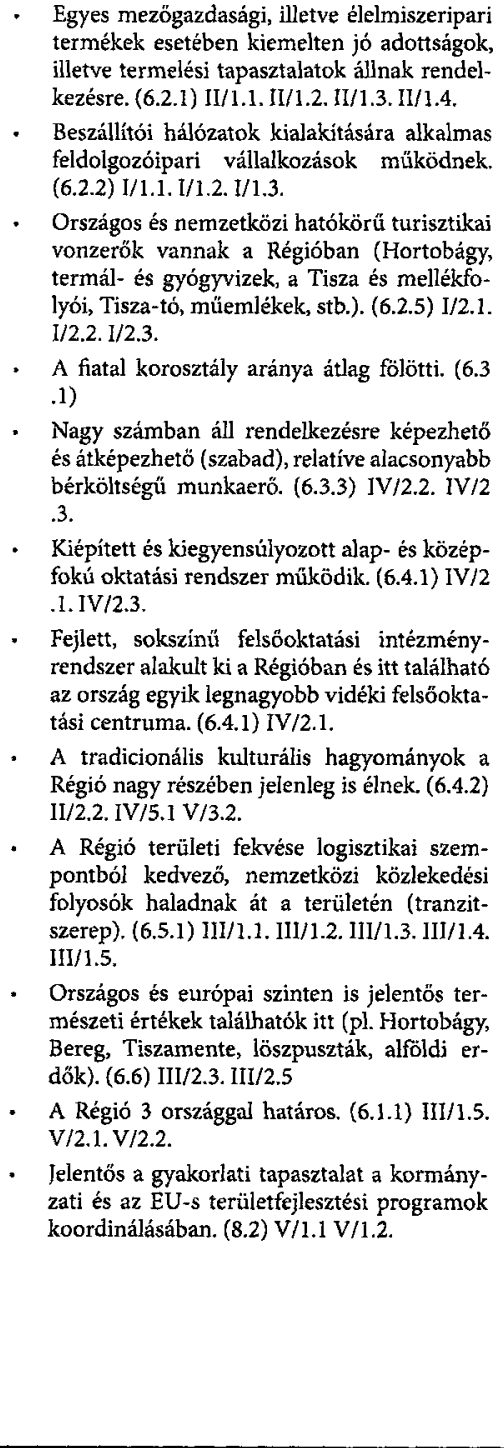 & 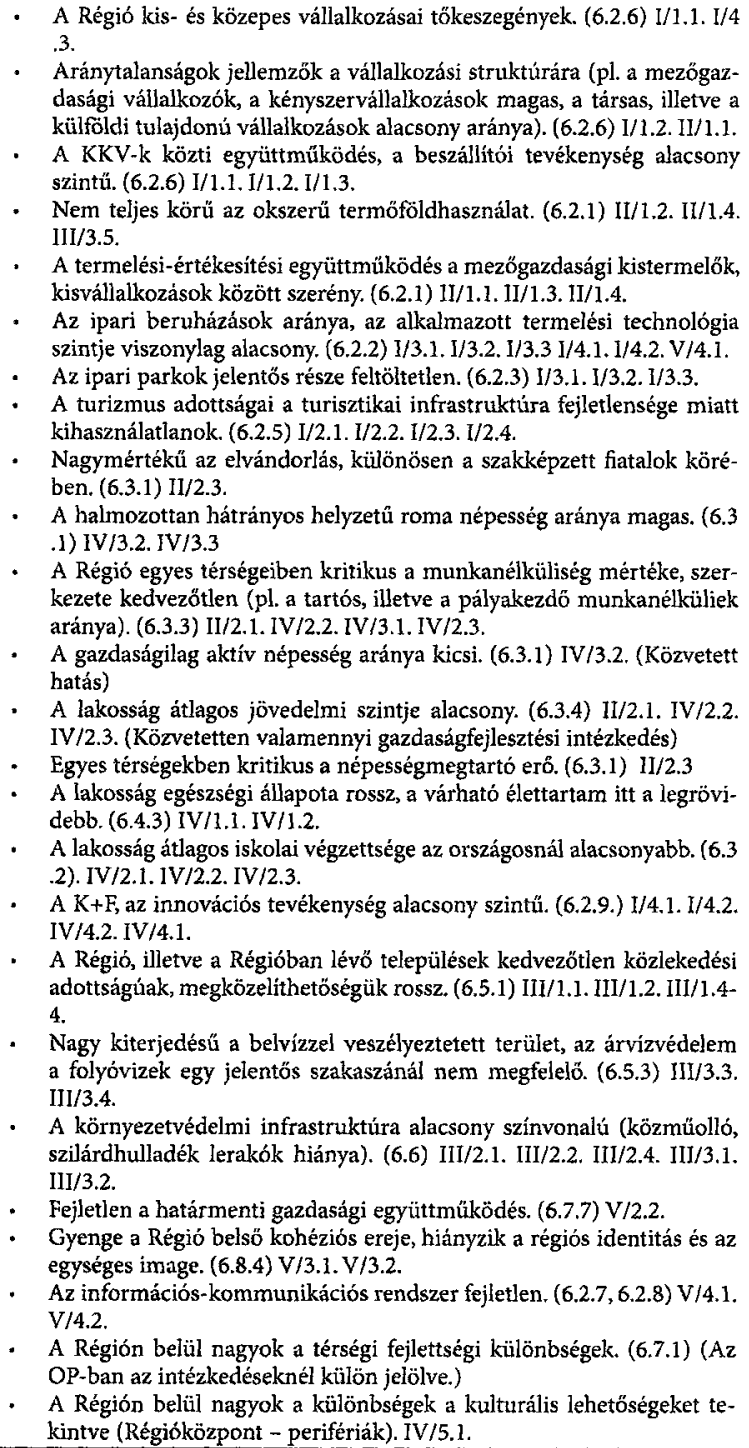 \\
\hline
\end{tabular}

Forrás: (Helyzetfeltárás 2003:789)

12 A zárójelben lévő számok a meghatározásokat alátámasz tó fejezetek számát jelzi.

${ }^{13}$ A római számmal kezdódö jelzések a Stratégiai (SP) és az Operatív Programban (OP) megjelenố intézkedések számozását jelentik, az egymásra épülö területfejlesztési dokumentumok konzisztenciáját mutatja be. 


\begin{tabular}{|c|c|}
\hline Lehetőségek & Veszélyek \\
\hline 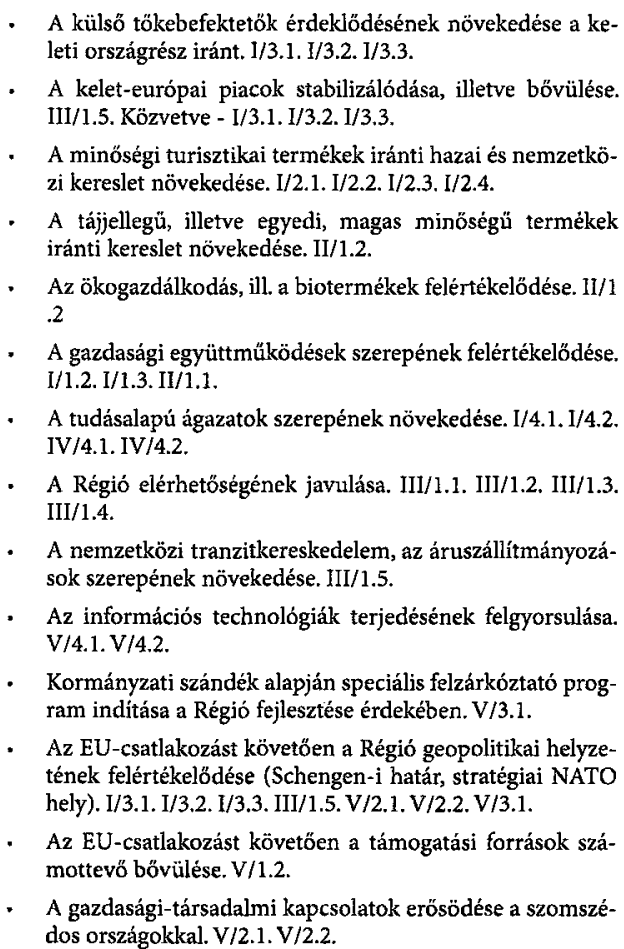 & 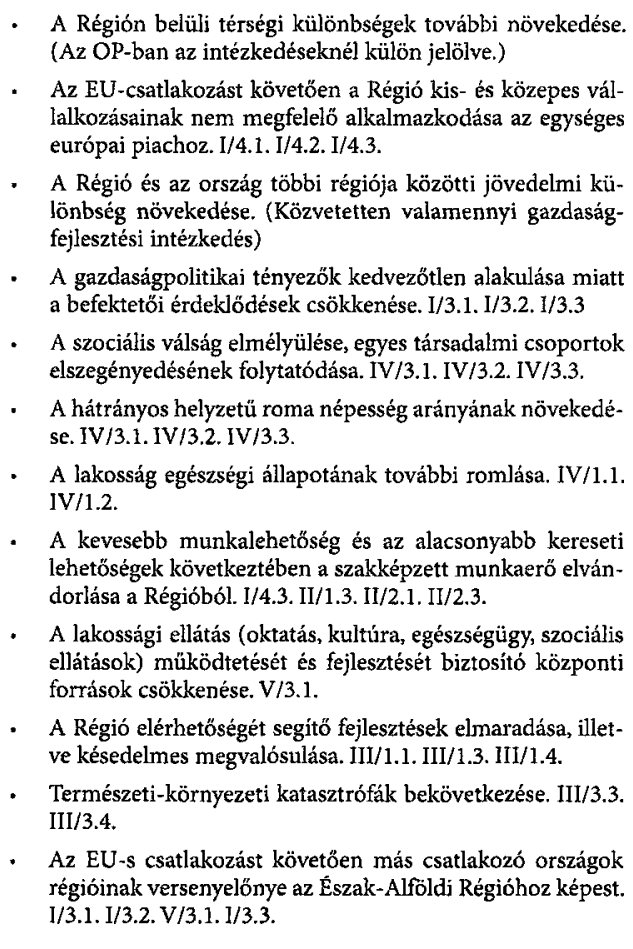 \\
\hline
\end{tabular}

